\title{
Synadenium umbellatum Pax. promotes cell cycle arrest and induces apoptosis in K-562 leukemia cells
}

\author{
Mariana Flavia da Mota, Polyana Lopes Benfica, Marize Campos Valadares*
}

Cellular Toxicology and Pharmacology Laboratory, Faculty of Pharmacy, Federal University of Goiás

\begin{abstract}
Chronic myeloid leukemia (CML) is a clonal myeloproliferative disease that shows apoptosis resistance. The introduction of imatinib mesylate has revolutionized the treatment of CML, but imatinib resistance may develop at any time and inevitably leads to disease progression. Synadenium umbellatum Pax. belongs to the Euphorbiaceae family and is popularly used in Brazil for the treatment of cancer. The cytotoxicity of Euphorbiaceae is associated with the ability of these plants and their bioactive compounds to induce apoptotic tumor cell death. Therefore, we aimed to investigate the cytotoxicity and the mechanisms of death induced by $S$. umbellatum extract in leukemic cells. $S$. umbellatum cytotoxicity was evaluated by trypan blue exclusion assay and flow cytometric analysis of the cell cycle; the mechanisms involved in K-562 cell death were investigated by light microscopy and flow cytometry. The results demonstrate that $S$. umbellatum is cytotoxic to leukemic cells in a concentration-dependent manner. Morphological analysis revealed that $S$. umbellatum treatment induced K-562 cell death by an apoptotic pathway. Furthermore, data indicate ROS overproduction, alterations in mitochondrial membrane potential, phosphatidylserine externalization and activation of caspase 9. Taken together, the results demonstrate that S. umbellatum extract arrested the cell cycle and triggered apoptosis at several levels in K-562 cells.
\end{abstract}

Uniterms: Synadenium umbellatum/pharmacognosy. Synadenium umbellatum/cytotoxicity/evaluation. K-562 cells/apoptosis. K-562 cells/cycle arrest.

\begin{abstract}
A leucemia mielóide crônica (LMC) é uma doença mieloproliferativa clonal, que apresenta resistência à apoptose. A introdução do mesilato de imatinibe revolucionou o tratamento da LMC, porém a resistência ao imatinibe pode ser desenvolvida em qualquer tempo e, inevitavelmente, leva à progressão da doença. Synadenium umbellatum Pax. pertence à família Euphorbiaceae e é usado popularmente no Brasil para o tratamento do câncer. A citotoxicidade das Euphorbiaceae está associada com a capacidade dessas plantas e seus compostos bioativos em induzir apoptose em células tumorais. Portanto, este trabalho teve como objetivo investigar a citotoxicidade e os mecanismos de morte induzidos por S. umbellatum em células leucêmicas. A citotoxicidade de $S$. umbellatum foi avaliada pelo ensaio de exclusão do azul de tripano e a análise do ciclo celular foi feita por citometria de fluxo. Os mecanismos envolvidos na morte celular das células K-562 foram investigados por microscopia óptica e por citometria de fluxo. Os resultados demonstraram que $S$. umbellatum é citotóxico para células leucêmicas de uma maneira dependente da concentração. A análise morfológica revelou que o tratamento com $S$. umbellatum induziu as célula K-562 à morte por via apoptótica. Além disso, os dados indicam aumento de $\mathrm{ERO}_{\mathrm{S}}$, alterações no potencial de membrana mitocondrial, externalização da fosfatidilserina e ativação de caspase 9. Em conjunto, os resultados demonstram que $S$. umbellatum promoveu retenção do ciclo celular das células K-562 e induziu estas células à morte por apoptose.
\end{abstract}

Unitermos: Synadenium umbellatum/farmacognosia. Synadenium umbellatum/citotoxicidade/avaliação. Célula K-562/apoptose. Célula K-562/retenção do ciclo.

\footnotetext{
*Correspondence: M.C. Valadares. Faculdade de Farmácia, Universidade Federal de Goiás. Praça Universitária esquina com a primeira avenida s/n, setor Universitário - 74605-220 - Goiânia, GO, Brasil. Phone / fax: +55 62 3209-6044 ext.22. E-mail: marizecv@farmacia.ufg.br
} 


\section{INTRODUCTION}

Chronic myeloid leukemia (CML) is a clonal myeloproliferative disease driven by the BCR-ABL fusion protein that arises from the translocation of chromosomes 9 and 22. This oncoprotein exhibits constitutively active kinase activity that confers growth potential and apoptosis resistance to CML cells (Cortez, Kadlec, Pendergast, 1995). BCR-ABL promotes cell division and blocks apoptosis, leading to unregulated growth of hematopoietic stem cells. Usually, patients with no chemotherapeutic treatment progress after several years from a chronic phase to a blast crisis, which can rapidly lead to death (O'Hare, Corbin, Druker, 2006).

The introduction of imatinib mesylate (Glivec/ Gleevec; Novartis Pharmaceuticals), a tyrosine kinase inhibitor, has revolutionized the treatment of CML. Imatinib is widely accepted as the standard of care for the first-line treatment of CML, due to its well-documented clinical activity, resulting in durable responses and prolonged survival. Moreover, toxicities associated with this therapy are considered low, and the main toxicities are myelosuppression, edema, and myalgia/arthralgia. On the other hand, imatinib resistance may develop at any time and inevitably leads to disease progression (Fausel, 2007). In this context, new agents are required for the treatment of CML.

Synadenium umbellatum Pax., a species of Euphorbiaceae widely found in South America, is popularly used in Brazil for the treatment of cancer. Studies performed by our group demonstrated scientific evidence for the effectiveness of $S$. umbellatum extract as an antitumor and antiangiogenic agent in vivo using the experimental model of Ehrlich ascitic tumor (EAT) (Nogueira et al., 2008). Recently, we also demonstrated the mechanisms of EAT cell death induced by $S$. umbellatum, in vitro. The cytotoxic effects found in EAT cells were mediated by activation of the intrinsic and extrinsic pathways of apoptosis. Furthermore, we determined by HPLC that the main constituents of $S$. umbellatum crude ethanolic extract are flavonoids and terpenes (Mota et al., 2012).

It has been reported in the literature that Euphorbiaceae species are cytotoxic against different tumor cell lines, especially K-562 leukemia cells. In most cases, this activity is associated with the ability of these plants to induce cell death, mainly by apoptotic mechanisms (Abreu et al., 2006; Amirghofran, et al., 2006; Block et al., 2005; Fatope et al., 1996; Grymberg et al., 1999; Itokawa et al., 1989; Kupchan et al., 1976; Kielland et al., 1996; Maciel et al., 2000; Morales et al., 2005; Ngamkitidechakul et al., 2010; Uthaisang et al., 2004).
In the present work, we investigated the cytotoxic activity of S. umbellatum in K-562 and Jurkat leukemia cell lines. Since K-562 is a BCR-ABL-expressing human leukemia cell line, with a drug resistance profile, the mechanisms of death induced by $S$. umbellatum were investigated in this cell model.

\section{MATERIALS AND METHODS}

\section{Reagents}

RPMI 1640 medium, fetal bovine serum, streptomycin, penicillin $\mathrm{G}$, propidium iodide, Giemsa dye, RNase, DCFH-DA, EDTA, rhodamine 123, and BSA were purchased from Sigma-Aldrich (St. Louis, MO, USA). Ethanol and trypan blue were obtained from Vetec (Rio de Janeiro, RJ, Brazil). Annexin V-FITC, binding buffer (TACS Annexin V-FITC apoptosis detection kit), caspase substrate 9, DTT, and lysis buffer (protease colorimetric assay kit) were acquired from R\&D Systems (Minneapolis, MN, USA). All reagents used were of analytical grade.

\section{Synadenium umbellatum Pax}

S. umbellatum $(17 \mathrm{~kg})$ aerial parts were collected in September 2005 in Goiânia, GO, Brazil (787 m altitude; $\left.16^{\circ} 40^{\prime} 15.5^{\prime \prime} \mathrm{S} ; 49^{\circ} 14^{\prime} 13.6^{\prime \prime} \mathrm{W}\right)$. Voucher specimens (No. UFG-27160) were deposited in the Herbarium of the Universidade Federal de Goiás (Instituto de Ciências Biológicas, Goiânia, GO, Brazil). Air-dried ground $S$. umbellatum material $(1.3 \mathrm{~kg}$ ) was exhaustively macerated in $95 \%$ ethanol (Vetec, RJ, Brazil), and after filtration, the extract was dried in a rotary evaporator (MA 120, Marconi, SP, Brazil) to dryness under low pressure and temperature to obtain $90 \mathrm{~g}$ of crude ethanolic extract $(6.9 \%$ yield $)$.

\section{Cell culture}

K-562 and Jurkat cell lines were obtained from the American type culture collection (ATCC, Rockville, MD, USA) and maintained in RPMI 1640 medium containing $10 \%$ heat-inactivated fetal bovine serum (FBS), $100 \mu \mathrm{g} / \mathrm{mL}$ streptomycin, $100 \mathrm{U} / \mathrm{mL}$ penicillin $\mathrm{G}$, and $2 \mathrm{mM} \mathrm{L}$-glutamine in a humidified atmosphere of $5 \% \mathrm{CO}_{2}$ in air at $37^{\circ} \mathrm{C}$. The cells were passaged twice a week and used in the exponential growth phase. Cell viability was determined by trypan blue exclusion.

\section{Cytotoxicity assay}

The viabilities of K-562 and Jurkat cells were evalu- 
ated using the trypan blue exclusion method. The cells $\left(1 \times 10^{6}\right.$ cells $\left./ \mathrm{mL}\right)$ were seeded in $96-$ well flat microtiter plates (Corning, USA) in RPMI 1640 medium supplemented with $10 \%$ FBS and incubated with or without eight concentrations $(0.007-1 \mathrm{mg} / \mathrm{mL})$ of $S$. umbellatum extract in six replicates for $24 \mathrm{~h}$. The cell suspension and a trypan blue solution $(0.2 \%$ in phosphate buffered saline - PBS) were mixed 1:10 and the viability of cells was estimated using a hemacytometer (Boeco, Germany). Stained cells were scored as dead. $\mathrm{IC}_{50}$ values (concentration that inhibited cell growth by $50 \%$, compared to untreated controls) were determined. For all subsequent assays, a value near the $\mathrm{IC}_{50}$ was used.

\section{Light microscopy}

The morphological alterations between K-562 cells untreated and treated with $S$. umbellatum were assessed by light microscopy. Untreated cells and cells treated with $0.06 \mathrm{mg} / \mathrm{mL}$ S. umbellatum extract were incubated for $24 \mathrm{~h}$ at $37^{\circ} \mathrm{C}$ and $5 \% \mathrm{CO}_{2}$ and, after incubation, placed on glass slides by cytospin and stained with Giemsa. After staining, the slides were examined by light microscopy (DM 2000, Leica microsystems, USA) and images were taken using a $40 \mathrm{x}$ objective amplified with $3 \mathrm{x}$ zoom (Canon Powershot S80).

\section{Cell cycle analysis}

K-562 cells $\left(1 \times 10^{6} / \mathrm{mL}\right)$ were incubated with or without $0.06 \mathrm{mg} / \mathrm{mL} \mathrm{S}$. umbellatum extract for $24 \mathrm{~h}$. After incubation, the cells were washed with ice-cold PBSEDTA, centrifuged at $296.82 \mathrm{~g}$ for $10 \mathrm{~min}$ and fixed with $2 \mathrm{~mL} 70 \%$ ice-cold ethanol at $4^{\circ} \mathrm{C}$ for $24 \mathrm{~h}$. After fixation, cells were washed again, resuspended in $500 \mu \mathrm{L}$ PBS solution containing $0.2 \mathrm{mg} / \mathrm{mL}$ RNAse and $0.05 \mathrm{mg} / \mathrm{mL}$ propidium iodide (PI), and then incubated at $4{ }^{\circ} \mathrm{C}$ for $2 \mathrm{~h}$. Fluorescence was measured with a FACSCanto II flow cytometer, using PE x FL2 channels. The assay was carried out in triplicate and 10,000 events were analyzed per experiment using the BDFACSDiva software.

\section{Measurement of intracellular ROS}

K-562 cells $\left(1 \times 10^{6} / \mathrm{mL}\right)$ were incubated with or without $0.06 \mathrm{mg} / \mathrm{mL}$ S. umbellatum extract for 12 and 24 h. Afterwards, cells were washed with PBS, centrifuged at $296.82 \mathrm{~g}$ for $10 \mathrm{~min}$ and incubated with $500 \mu \mathrm{L} \mathrm{DCFH-}$ $\mathrm{DA}(10 \mu \mathrm{M})$ for $1 \mathrm{~h}$, and fluorescence determined by flow cytometry using the FL1 channel.

\section{Assessment of mitochondrial membrane potential $(\Delta \psi \mathrm{m})$}

K-562 Cells (1x10\% $/ \mathrm{mL})$, untreated and treated with $0.06 \mathrm{mg} / \mathrm{mL} \mathrm{S}$. umbellatum extract for $24 \mathrm{~h}$, were washed with PBS-EDTA, centrifuged at $296.82 \mathrm{~g}$ for $10 \mathrm{~min}$, and incubated with $1 \mu \mathrm{g} / \mathrm{mL}$ rhodamine 123 at $37^{\circ} \mathrm{C}$ for $1 \mathrm{~h}$, and the fluorescence determined by flow cytometry, using the FL1 channel.

\section{Annexin V-FITC/PI double-staining for phosphatidylserine externalization analysis}

K-562 Cells ( $\left.1 \times 10^{6} / \mathrm{mL}\right)$, untreated and treated with $0.06 \mathrm{mg} / \mathrm{mL}$ S. umbellatum extract for $24 \mathrm{~h}$, were washed with PBS-BSA and centrifuged at $296.82 \mathrm{~g}$ for $10 \mathrm{~min}$. The cells were then incubated for 15 min with $100 \mu \mathrm{L}$ binding buffer (10 mmol/L HEPES/NaOH, $140 \mathrm{mmol} / \mathrm{L}, \mathrm{NaCl} 2.5$ $\mathrm{mmol} / \mathrm{L} \mathrm{CaCl}_{2}$ ) with $1 \mu \mathrm{L}$ annexin V-FITC and $10 \mu \mathrm{L}$ PI solution, and analyzed by flow cytometry. Fluorescence of annexin V-FITC and PI was measured using the FL1 and FL2 channels, respectively.

\section{Caspase activity}

The activity of caspase 9 was measured using a colorimetric protease assay kit, following the manufacturer's instructions. After $24 \mathrm{~h}$ of incubation with or without $0.015 \mathrm{mg} / \mathrm{mL}$ S. umbellatum extract, K-562 cells $\left(1 \times 10^{6} / \mathrm{mL}\right)$ were washed with ice-cold PBS, centrifuged at $296.82 \mathrm{~g}$ for $10 \mathrm{~min}$ and incubated on ice for $20 \mathrm{~min}$ with $25 \mu \mathrm{L}$ of cell-lysis buffer (provided in the kit). The cell lysate was collected by centrifugation at $29,682.9 \mathrm{~g}$ at $4{ }^{\circ} \mathrm{C}$ for $15 \mathrm{~min}$. The assay was performed in 96 well plates containing $50 \mu \mathrm{L}$ cell lysate, $50 \mu \mathrm{L} 2 \mathrm{x}$ reaction buffer, $5 \mu \mathrm{L}$ caspase colorimetric substrate and $10 \mu \mathrm{L}$ DTT. Duplicate wells were prepared containing blank (no cell extract), negative control (extract from untreated cells), positive controls (no cell lysate and no substrate) and $S$. umbellatum-treated cells. The plates were incubated at $37^{\circ} \mathrm{C}$ for $2 \mathrm{~h}$, and absorbance was read with a microplate reader (Stat Fax 2100, Awareness Technology, Germany) at $405 \mathrm{~nm}$. Caspase 9 activity was determined by measuring $p$-nitroanaline ( $p \mathrm{NA}$ ) released during the cleavage of LEHD- $p$ NA substrate.

\section{Statistical analysis}

Statistical analysis was performed using Graph Pad Prism 5 (version 5.00 for Windows 98, Graph Pad Software, San Diego, CA) software. The evaluation of cytotox- 
icity was carried out in three separate experiments. Results were converted to percentages of the control and $\mathrm{IC}_{50}$ values were obtained by non-linear regression analysis. Results are expressed as the mean $\pm \mathrm{SD}$ of six replicates. All other assays were analysed by Student's $t$-test. Results were considered statistically significant when $P<0.05$.

\section{RESULTS}

\section{Cytotoxic effects of $S$. umbellatum in leukemic cells}

S. umbellatum cytotoxicity was evaluated in the leukemic cell lines, K-562 and Jurkat, by the trypan blue exclusion method, after $24 \mathrm{~h}$ of exposure to different concentrations $(0.007-1 \mathrm{mg} / \mathrm{mL})$. As shown in Figure 1, both cell lines studied were highly sensitive to $S$. umbellatum extract, in a concentration-dependent manner. Differences in the susceptibility of the two leukemic cell lines to $S$. umbellatum were observed in the $\mathrm{IC}_{50}$ values $\left(\mathrm{IC}_{50}\right.$ Jurkat $=0.041 \mathrm{mg} / \mathrm{mL}$ and $\mathrm{IC}_{50} \mathrm{~K}-562=$ $0.073 \mathrm{mg} / \mathrm{mL}$ ). Additionally, the effects of S. umbellatum on normal lymphocytes from primary culture were studied; these experiments revealed a high cytotoxic activity (data not shown). Based on these findings, the K-562 cell line was chosen for subsequent mechanistic studies.

\section{K-562 cell morphology after $S$. umbellatum treatment}

Morphological analysis of K-562 cells stained with Giemsa revealed alterations after treatment with $S$. umbellatum extract. As can be seen in Figure 2A, control cells exhibited nuclei with dispersed chromatin and organized

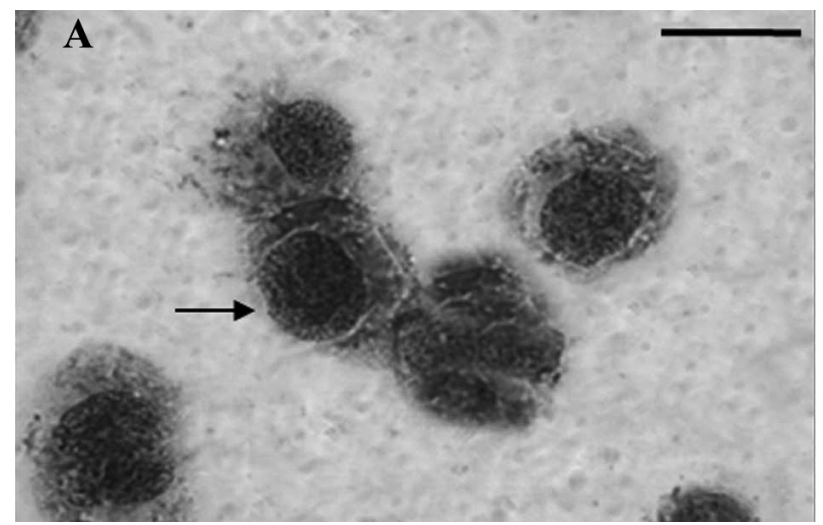

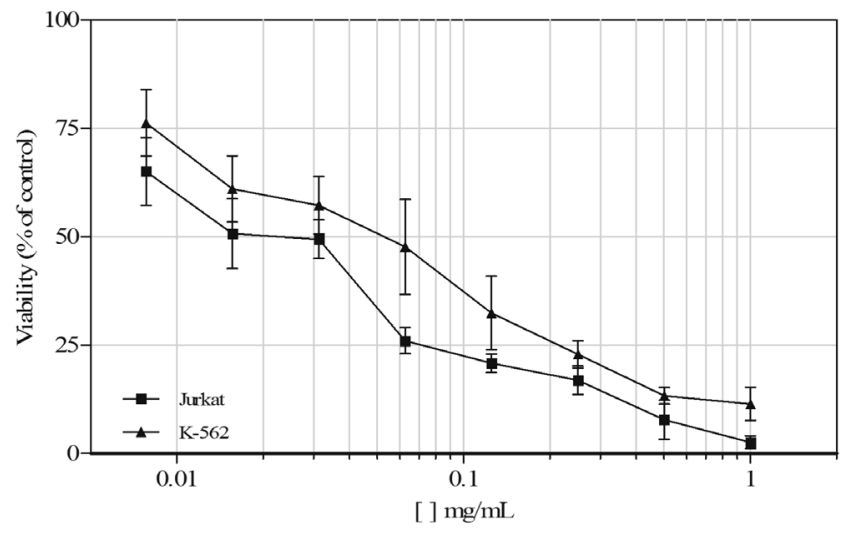

FIGURE 1 - Cytotoxic effects of Synadenium umbellatum extract on K-562 and Jurkat cells after $24 \mathrm{~h}$ of treatment $(0.007-1 \mathrm{mg} / \mathrm{mL})$. The cytotoxic activity was determined by trypan blue exclusion assay. Experiments were performed in sextuplicate. Each bar presents the mean $\pm \mathrm{SD}$ of three independent experiments. The $\mathrm{IC}_{50}$ was $0.041 \mathrm{mg} / \mathrm{mL}$ and $0.073 \mathrm{mg} / \mathrm{mL}$ in Jurkat and K-562 cells, respectively.

plasma membrane. In contrast, cells treated with $S$. umbellatum for $24 \mathrm{~h}$ (Figure 2B) showed membrane blebbing and chromatin condensation. These microscopic changes, caused by $S$. umbellatum treatment, suggested an activation of apoptosis.

\section{Effects of $S$. umbellatum in cell cycle distribution}

Flow cytometric analysis revealed changes in cell cycle progression between untreated and treated K-562 cells (Figures 3A, B). S. umbellatum extract $(0.06 \mathrm{mg} / \mathrm{mL})$ increased the number of cells in $\mathrm{G}_{0} / \mathrm{G}_{1}$ phases by $19.7 \pm$ $7.9 \%(P<0.05)$, followed by a reduction of $74.0 \pm 2.4 \%$ in the $\mathrm{S}$ phase $(P<0.001)$ and an increase of $51.2 \pm 5.7 \%$

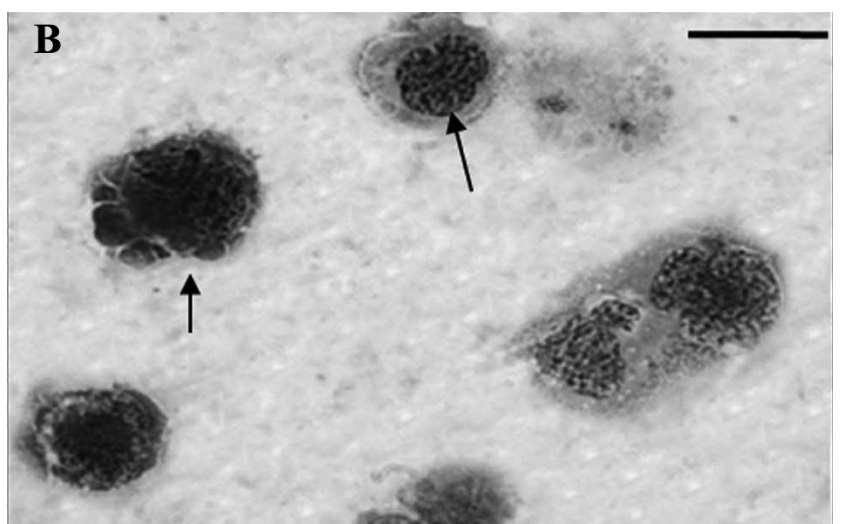

FIGURE 2 - Morphological changes of Synadenium umbellatum-induced apoptosis in K-562 cells. Cells were treated with $0.06 \mathrm{mg} / \mathrm{mL}$ Synadenium umbellatum extract for $24 \mathrm{~h}$ and images were taken using a $40 \mathrm{x}$ objective amplified with $3 \mathrm{x}$ zoom. (A) Control cells stained with Giemsa, showing nuclei with dispersed chromatin and organized plasma membrane (arrow). (B) Synadenium umbellatum-treated cells displaying membrane blebbing and chromatin condensation (arrows). Bars: $20 \mu \mathrm{m}$. 

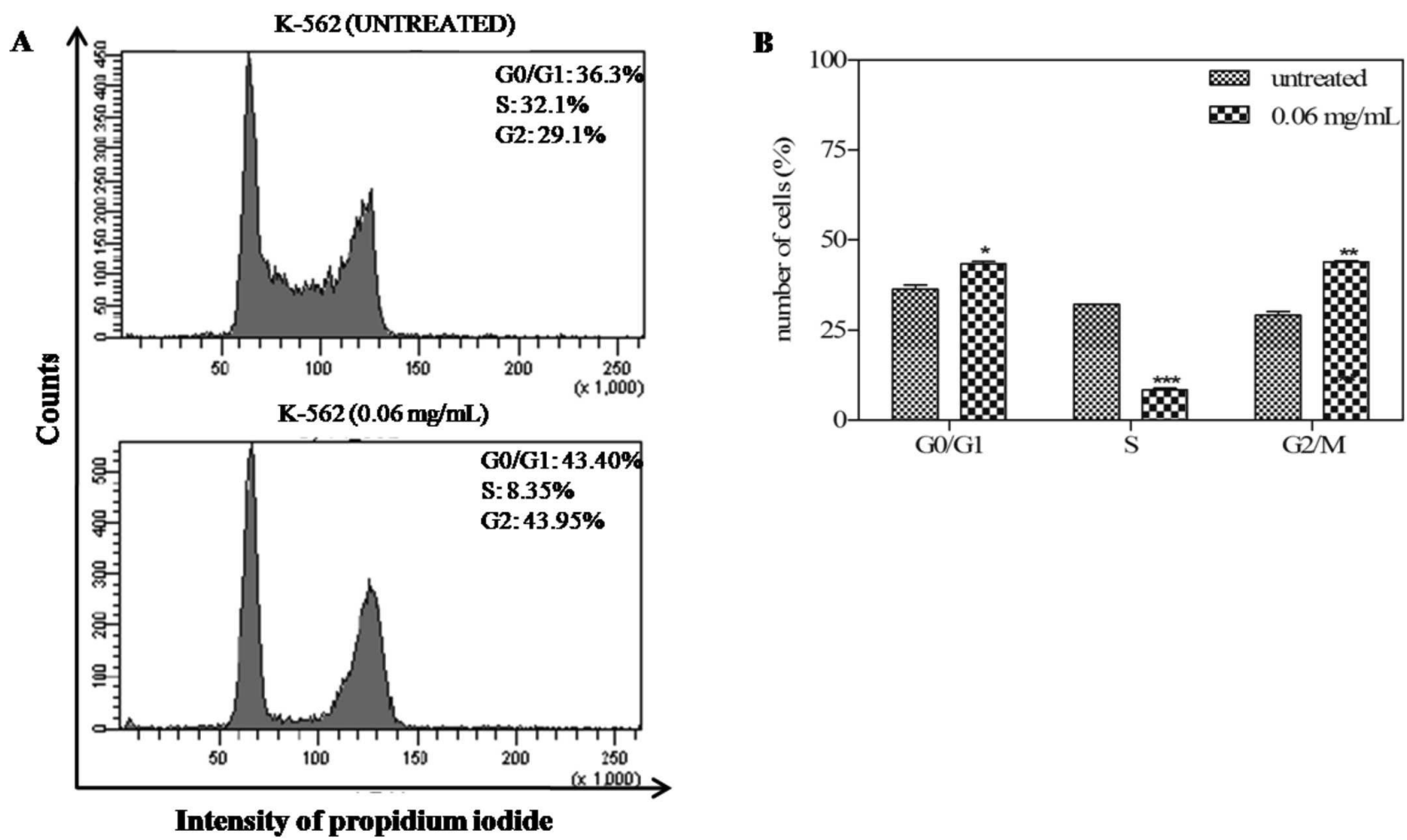

FIGURE 3 - Flow cytometry analysis of K-562 cell cycle with and without treatment with Synadenium umbellatum extract (0.06 $\mathrm{mg} / \mathrm{mL}$ ) for $24 \mathrm{~h}$. (A) Histograms showing cells untreated and treated with $0.06 \mathrm{mg} / \mathrm{mL} \mathrm{S}$. umbellatum for $24 \mathrm{~h}$. (B) Percentage of $\mathrm{K}-562$ cells in $\mathrm{G}_{1}, \mathrm{~S}$ and $\mathrm{G}_{2}$ phases with and without $S$. umbellatum treatment. Each bar represents the mean $\pm \mathrm{SD}$ of two independent experiments $(* P<0.05 ; * * P<0.01 ; * * * P<0.001)$.

in $\mathrm{G}_{2}(P<0.01)$. These results suggest that $S$. umbellatum arrested K-562 cells in the $\mathrm{G}$ phases.

\section{S. umbellatum-induced oxidative stress}

In addition to cell cycle arrest and morphological changes induced by $S$. umbellatum treatment, a timedependent increase in intracellular ROS was found after 12 and $24 \mathrm{~h}$ of incubation with $0.06 \mathrm{mg} / \mathrm{mL} \mathrm{S}$. umbellatum extract. As shown in Figure 4, the generation of ROS dramatically increased with incubation time. Treatment with S. umbellatum for $12 \mathrm{~h}$ increased intracellular ROS levels by $36.2 \pm 13.7 \%$, reaching $111.4 \%$ at $24 \mathrm{~h}$ $(P<0.05)$.

\section{S. umbellatum-induced alterations in mitochondrial membrane potential}

The most common alteration in $\Delta \psi m$ after oxidative stress is cellular depolarization, but an early hyperpolarization can occur. As shown in Figure 5, treatment with 0.06 $\mathrm{mg} / \mathrm{mL}$ S. umbellatum extract for $24 \mathrm{~h}$ increased $\Delta \psi \mathrm{m}$ in $\mathrm{K}-562$ cells by $117.6 \pm 1.9 \%$.

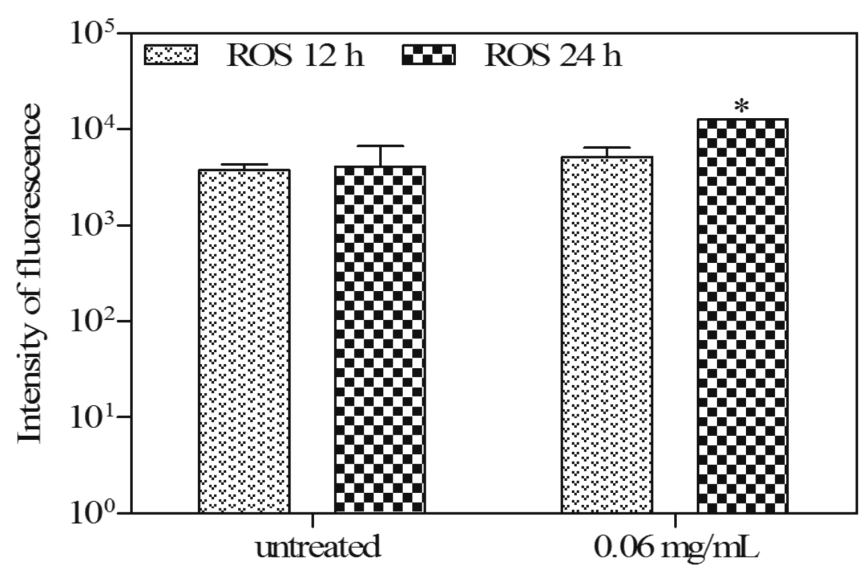

FIGURE 4 - Effects of $S$. umbellatum treatment of $\mathrm{K}-562$ cells on ROS generation. Cells were treated with $0.06 \mathrm{mg} / \mathrm{mL}$ S. umbellatum extract for 12 and $24 \mathrm{~h}$, incubated with $10 \mu \mathrm{M}$ DCFH-DA for $1 \mathrm{~h}$ and analyzed by flow cytometry ( ${ }^{*} P<0.05$ compared to untreated).

\section{Phosphatidylserine exposure, induced by S. umbellatum}

To differentiate cells undergoing apoptosis by PS 
exposure or necrosis by rupture of plasma membrane in $S$. umbellatum-mediated cell death, K-562 cells were labeled with annexin V-FITC (A) and PI. As shown in Figure 6,

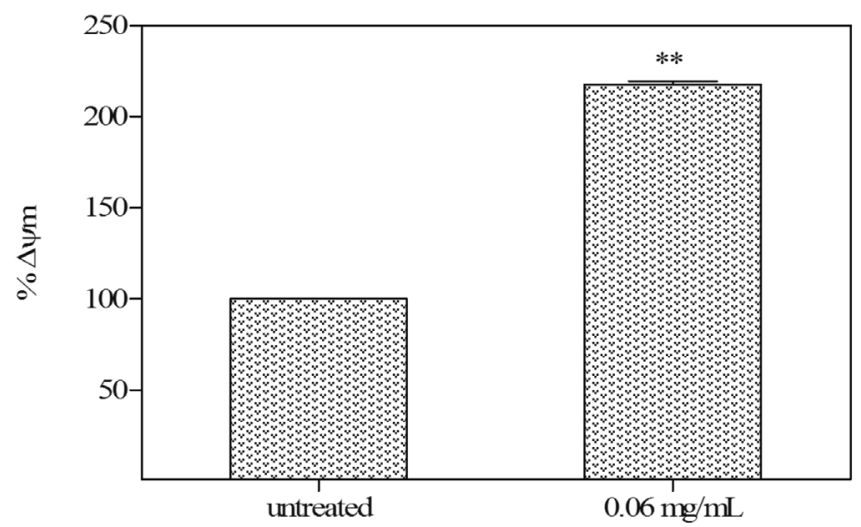

FIGURE 5 - Effect of Synadenium umbellatum on mitochondrial membrane potential $(\Delta \psi \mathrm{m})$ of K-562 cells. The graph shows rhodamine 123 intensity of untreated cells and cells treated with $0.06 \mathrm{mg} / \mathrm{mL} S$. umbellatum extract for $24 \mathrm{~h}(* * P<0.01)$. after $24 \mathrm{~h}$ of treatment with $0.06 \mathrm{mg} / \mathrm{mL} \mathrm{S.} \mathrm{umbellatum}$ extract, the number of live cells (A-/PI-) decreased by 16.0 $\pm 0.8 \%(P<0.01)$, while the number of apoptotic cells $(\mathrm{A}+/ \mathrm{PI}+)$ increased by $286.1 \pm 30.8 \%(P<0.001)$.

\section{Activation of caspase 9 by $S$. umbellatum}

To investigate whether caspases were activated during $S$. umbellatum-induced cell death, a colorimetric assay was performed. As shown in Figure 7, after $24 \mathrm{~h}$ of exposure to $0.015 \mathrm{mg} / \mathrm{mL} \mathrm{S}$. umbellatum, there was a significant increase in caspase 9 activity $(15.9 \pm 0.4 \%)$, as detected by cleavage of LEHD- $p$ NA substrate. Thus, induction of caspase activity may be involved in $S$. umbellatuminduced apoptosis.

\section{DISCUSSION AND CONCLUSION}

In the present study, a BCR-ABL-expressing human leukemic cell line, K562, was used as a model system of resistance to apoptosis induced by conventional chemo-

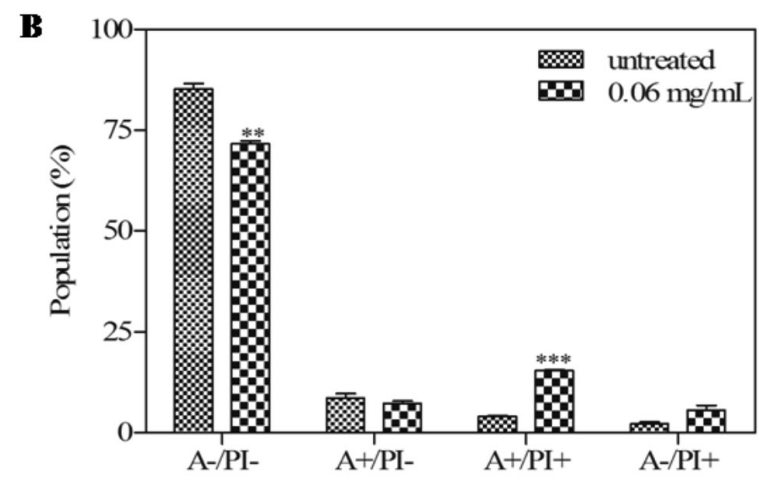

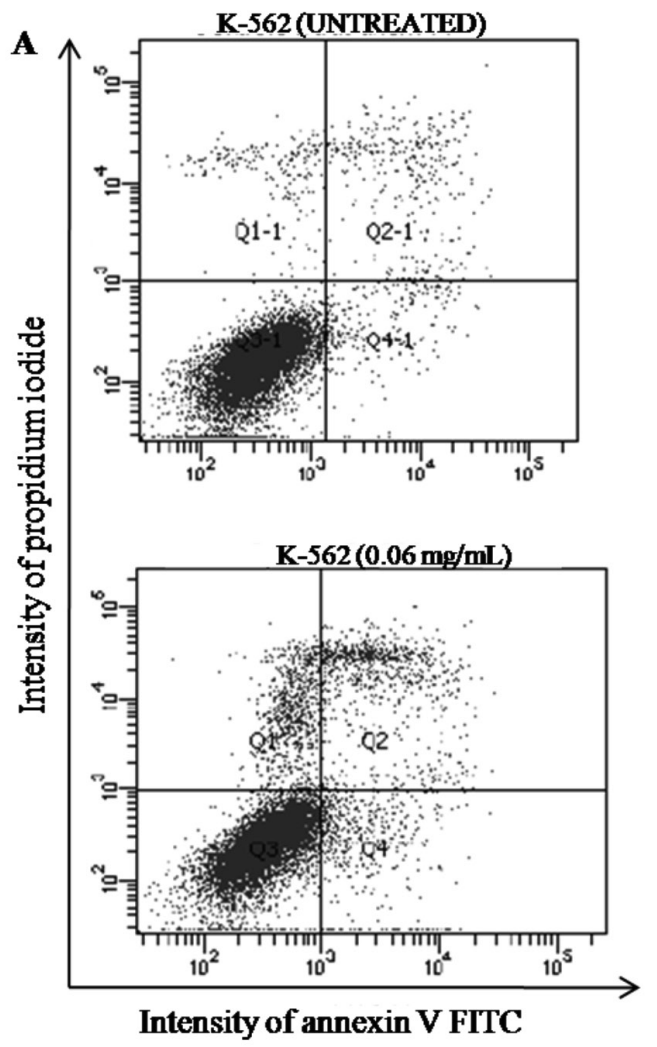

FIGURE 6 - Flow cytometry analysis of phosphatidylserine externalization in Synadenium umbellatum-treated K-562 cells. Cells were labeled with annexin V-FITC and PI. (A) Untreated cells and cells treated with $0.06 \mathrm{mg} / \mathrm{mL} \mathrm{S.} \mathrm{umbellatum} \mathrm{for} 24 \mathrm{~h}$. Lower left quadrants (A-/PI-) $=\%$ of viable cells. Lower right quadrants (A+/PI-) $=\%$ of early apoptotic cells. Upper left quadrants $(\mathrm{A}+/ \mathrm{PI}+)=\%$ of late apoptotic cells. Upper right quadrants (A-/PI +$)=\%$ of necrotic cells. (B) Comparison of fluorescence intensity of annexin V-FITC and PI between untreated and S. umbellatum-treated cells. The bar represents the mean $\pm \mathrm{SD}$ of two independent experiments $(* * P<0.01 ; * * * P<0.001$ compared to untreated). 


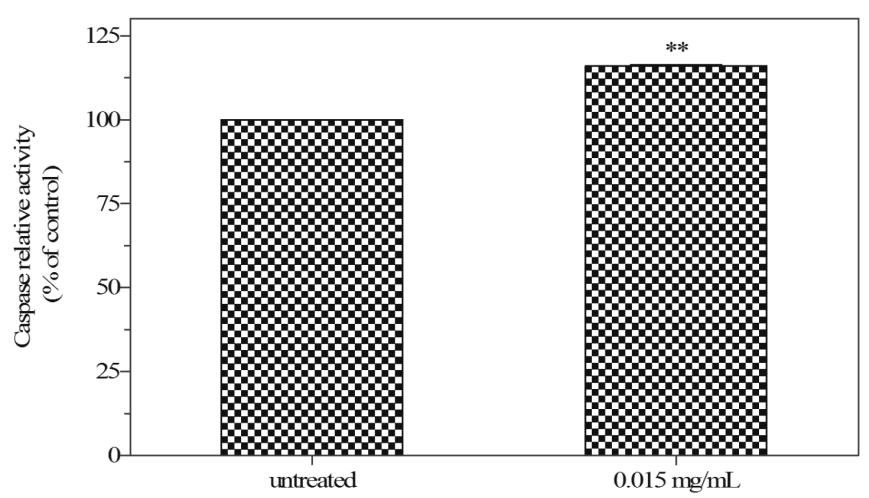

FIGURE 7 - Activation of caspase 9 during Synadenium umbellatum-induced apoptosis. K-562 cells were treated with $0.015 \mathrm{mg} / \mathrm{mL}$ S. umbellatum extract for $24 \mathrm{~h}$. Kinetics of the enzymatic activity of caspase 9 was evaluated. Each bar represents the mean $\pm \mathrm{SD}$ of two independent experiments (* $P<0.05$ compared to control).

therapeutics to investigate the mechanisms of the antitumor activity found in $S$. umbellatum. The results presented herein showed that $S$. umbellatum was cytotoxic to human leukemia cells. The mechanistic investigation using K-562 showed that $S$. umbellatum promoted cell growth arrest and induced death via apoptosis by increasing ROS production, alterations in mitochondrial functions, PS externalization and activation of caspases.

Plant families possessing bioactive compounds, particularly terpenes, have shown antitumor properties (Mota et al., 2012). The cytotoxic activity of the Euphorbiaceae has been associated with induction of apoptosis in tumor cells. The extract of Croton malambo H. Karst. was reported to induce tumor cell apoptosis (Morales et al., 2005). In this study, we demonstrated morphological and biochemical changes in K-562 cells after $S$. umbellatum treatment, corroborating the reported induction of apoptosis by Euphorbia cheiradenia Boiss. \& Hohen. in K-562 cells (Amirghofran et al., 2006).

For the apoptotic process, a disruption of mitochondrial membrane integrity is decisive. An increase in ROS production and consequent loss of $\Delta \psi \mathrm{m}$ are reported as typical phenomena in the process of mitochondrialmediated apoptosis (Fang et al., 2007). Mitochondrial membrane depolarization is a universal event in apoptosis, but it has been suggested that the inner membrane of mitochondria may undergo a transient hyperpolarization during apoptosis (Liu et al., 2005; Matsuyama, Reed, 2000; Poot, Pierce, Kavanagh, 2002). Our data revealed an increase in ROS levels, followed by an early increase in $\Delta \psi m$ (hyperpolarization) after $S$. umbellatum treatment, suggesting that apoptosis, induced by $S$. umbellatum, is mitochondriadependent. S. umbellatum-induced apoptosis in K-562 cells also promoted PS externalization, an event that occurs during the effector phase of apoptosis (Van Engeland et al., 1998), as observed for the VR-3848 peptide, isolated from a Euphorbiaceae plant, which induced leukemic cells to undergo apoptosis through negative modulation of the anti-apoptotic protein Bcl-2, nuclear condensation, DNA fragmentation, caspase activation and PS externalization (Uthaisang et al., 2004).

Caspases play a critical role in the progression of apoptosis; activation of caspases takes place via the extrinsic or caspase 8-mediated and the intrinsic or caspase 9-mediated pathways. Both pathways can converge to activate effector caspases, which induce changes characteristic of apoptosis (Datta et al., 2009). In this study, we demonstrated that apoptosis, mediated by $S$. umbellatum, involved the activation of caspase 9 . This finding suggests that $S$. umbellatum induced apoptosis in K-562 cells by the mitochondrial pathway. Corroborating our findings, diterpenes isolated from Croton zambesicus Müll. Arg. (Euforbiaceae) have also been found to induce apoptosis in human leukemic cells by caspase activation (Block et al., 2005).

Inhibition of cancer growth has been a continuous target in cancer treatment. A reduction in cell growth and an induction of cell death are two major mechanisms that may be employed to inhibit tumor growth (Zhang et al., 2009). In this study, we demonstrated that, in addition to the induction of leukemic cell death, S. umbellatum also promoted an inhibition of the growth of these cells, by a cell cycle arrest, increasing the number of cells in $\mathrm{G}_{1}$ and $\mathrm{G}_{2}$ in parallel with a reduction in the phase $\mathrm{S}$. In agreement with these findings, the anti-proliferative effect of jolkinolide B in K-562 cells is reported to result from the arrest of the cell cycle in the $\mathrm{G}_{0} / \mathrm{G}_{1}$ phase and the subsequent induction of apoptosis (Luo, Wang, 2006).

Taken together, our data showed that S. umbellatum is cytotoxic to human leukemia cells, promoting cell growth inhibition and inducing death via apoptosis by an increase in ROS generation, alterations in mitochondrial functions, PS externalization and activation of caspase 9. Considering the clinical limitations in CML treatment, it is clear that new agents with different mechanisms of action are desired, both for primary treatment and as adjuvant to improve cancer therapy.

\section{ACKNOWLEDGMENTS}

This study was supported by Fundação de Apoio à Pesquisa (FUNAPE) UFG, Goiânia-GO, Conselho Nacional de Desenvolvimento Científico e Tecnológico (CNPq), Financiadora de Estudo e Projetos (FINEP) and 
Coordenação de Aperfeiçoamento de Pessoal de Nível Superior (CAPES).

\section{REFERENCES}

ABREU, P.; MATTHEW, S.; GONZÁLEZ, T.; COSTA, D.; SEGUNDO, M.A.; FERNANDES, E. Anti-inflammatory and antioxidant activity of a medicinal tincture from Pedilanthus tithymaloides. Life Sci., v.78, p.1578-1585, 2006.

AMIRGHOFRAN, Z.; BAHMANI, M.; AZADMEHR, A.; JAVIDNIA, K. Induction of apoptosis in leukemia cell lines by Linum persicum and Euphorbia cheiradenia. $J$. Cancer Res. Clin. Oncol., v.132, p.427-432, 2006.

BLOCK, S.; GERKENS, P.; PEULEN, O.; JOLOIS, O.; MINGEOT-LECLERCQ, M.P.; DE PAUW-GILLET, M.C.; QUETIN-LECLERCQ, J. Induction of apoptosis in human promyelocytic leukemia cells by a natural trachylobane diterpene. Anticancer Res., v.25, p.363-368, 2005.

CORTEZ, D.; KADLEC, I.; PENDERGAST, A.M. Structural and signaling requirement for BCR-ABL-mediated transformation and inhibition of apoptosis. Mol. Cell Biol., v.15, p.5531-5541, 1995.

DATTA, S.; MAZUMDER, S.; GROSH, D.; DEY, S.; BHATTACHARYA, S. Low concentration of arsenic could induce caspase-3 mediated head kidney macrophage apoptosis with JNK-p38 activation in Clarias batrachus. Toxicol. Appl. Pharmacol., v.241, p.329-338, 2009.

FANG, L.; HE, Q.; HU, Y.; YANG, B. MZ3 induces apoptosis in human leukemia cells. Cancer Chemother. Pharmacol., v.59, p.397-405, 2007.

FATOPE, M.O.; ZENG, L.; OHAYAGA, J.E.; SHI, G.; McLAUGHLIN, J.L. Selectively cytotoxic diterpenes from Euphorbia poisonii. J. Med. Chem., v.39, p.1005-1008, 1996.

FAUSEL, C. Targeted chronic myeloid leukemia therapy: seeking a cure. J. Manag. Care Pharm., v.13, p.8-12, 2007.

GRYMBERG, N.F.; ECHEVARRIA, A.; LIMA, J.E.; PAMPLONA, S.S.R.; PINTO, A.C.; MACIEL, M.A.M. Anti-tumour activity of two 19-nor-clerodane diterpenes, trans-dehydrocrotonin and trans-crotonin, from Croton cajucara. Planta Med., v.65, p.687-689, 1999.
ITOKAWA, H.; ICHIHARA, Y.; WATANABE, K.; TAKEYA, K. An antitumor principle from Euphorbia lathyris. Planta Med., v.55, p.271-272, 1989.

KIELLAND, I.S.; DORNISH, J.M.; MALTERUD, K.E.; HVISTENDAHL, G.; ROMMING, C.; BOCKMAN, O.C.; KOLSAKER, P.; STENSTROM, Y.; NORDAL, A. Cytotoxic triterpenoids from the leaves of Euphorbia pulcherrima. Planta Med., v.62, p.322-325, 1996.

KUPCHAN, S.M.; UCHIDA, I.; BRANFMAN, A.R.; DAILEY JR., R.G.; FEI, B.Y. Antileukemic principles isolated from Euphorbiaceae plants. Science, v.191, p.571-572, 1976.

LIU, M.J.; WANG, Z.; JU, Y.; WONG, R.N.S.; WU, Q.Y. Diosgenin induces cell cycle arrest and apoptosis in human leukemia K562 cells with the disruption of $\mathrm{Ca}^{2+}$ homeostasis. Cancer Chemother. Pharmacol., v.55, p.7990, 2005.

LUO, H.; WANG, A. Induction of apoptosis in K562 cells by jolkinolide B. Can. J. Physiol. Pharmacol., v.84, p.959965, 2006.

MACIEL, M.A.M.; PINTO, A.C.; ARRUDA, A.C.; PAMPLONA, S.G.S.R.; VANDERLINDE, F.A.; LAPA, A.J.; ECHEVARRIA, A.; GRYNBERG, N.F.; CÔLUS, I.M.S.; FARIAS, R.A.F.; COSTA, A.M.L.; RAO, V.S.N. Ethnopharmacology, phytochemistry and pharmacology: a successful combination in the study of Croton cajucara. J. Ethnopharmacol., v.70, p.41-55, 2000.

MATSUYAMA, S.; REED, J.C. Mitochondria-dependent apoptosis and cellular $\mathrm{pH}$ regulation. Cell Death Differ., v.7, p.1155-1165, 2000.

MORALES, A.; PÉREZ, P.; MENDOZAB，R.; COMPAGNONEC, R.; SUAREZ, A.I.; ARVELOB, F.; RAMÍREZ, J.L.; GALINDO-CASTRO, I. Cytotoxic and proapoptotic activity of ent-16b-17a-dihydroxykaurane on human mammary carcinoma cell line MCF-7. Cancer Lett., v.218, p.109-116, 2005.

MOTA, M.F.; BENFICA, P.L.; BATISTA, A.C.; MARTINS, F.S.; PAULA, J.R.; VALADARES, M.C. Investigation of Ehrlich ascites tumor cell death mechanisms induced by Synadenium umbelatum Pax. J. Ethnopharmacol., v.139, p.319-329, 2012. 
NGAMKITIDECHAKUL, C.; JAIJOY, K.; HANSAKUL, P.; SOONTHORNCHAREONNON, N.; SIREERATAWONG, S. Antitumour effects of Phyllanthus emblica L.: induction of cancer cell apoptosis and inhibition of in vivo tumour promotion and in vitro invasion of human cancer cells. Phytother. Res., v.24, p.1405-1413, 2010.

NOGUEIRA, I.A.L.; LEÃO, A.B.B.; VIEIRA, M.S.; BENFICA, P.L.; CUNHA, L.C.; VALADARES, M.C. Antitumoral and antiangiogenic activity of Synadenium umbellatum Pax. $J$. Ethnopharmacol., v.120, p.474-478, 2008.

O'HARE, T.; CORBIN, A.S.; DRUKER, B.J. Targeted CML therapy: controlling drug resistance, seeking cure. Curr. Opin. Genet. Dev., v.16, p.92-99, 2006.

POOT, M.; PIERCE, R.H.; KAVANAGH, T.J. Flow cytometric and fluorometric methods of quantifying and characterizing apoptotic cell death. In: DAVIS, M. A. (Ed.). Apoptosis methods in pharmacology and toxicology. Totowa: Humana Press, 2002. p.11-36.
UTHAISANG, W.; REUTRAKUL, V.; KRACHANGCHAENG, C.; WILAIRAT, P.; FADEEL, B. VR-3848, a novel peptide derived from Euphobiaceae, induces mitochondriadependent apoptosis in human leukemia cells. Cancer Lett., v.28, p.171-178, 2004.

VAN ENGELAND, M.; NIELAND, L.J.W.; RAMAEKERS, F.C.S.; SCHUTTE, B.; REUTELINGSPERGER, C.P.M. Annexin V-affinity assay: a review on an apoptosis detection system based on phosphatidylserine exposure. Cytometry, v.31, p.1-9, 1998.

ZHANG, Y.B.; YEB, Y.P.; WUC, X.D.; SUN, H.X. Astilbotriterpenic acid induces growth arrest and apoptosis in HeLa cells through mitochondria-related pathways and reactive oxygen species (ROS) production. Chem. Biodivers., v.6, p.218-230, 2009.

Received for publication on $06^{\text {th }}$ December 2012 Accepted for publication on $29^{\text {th }}$ May 2012 
